\title{
DEFINITION FORMATION PROCESS OF LANGUAGE LEARNING STRATEGY: ISSUES AND DEVELOPMENT
}

\author{
Kamarul Shukri Mat Teh \\ Faculty of Languages and Communication \\ Universiti Sultan Zainal Abidin \\ kamarul@unisza.edu.my
}

\begin{abstract}
Orientation of language learning strategy (LLS) research which was not based on solid theory in the early stages, and differences in second and foreign language learning setting have led to the formation of LLS terminologies and definition that are inconsistent and divergent. This situation has resulted in conflicting views among researchers. Hence, this paper attempts to identify issues and developments that occur in the process of defining LLS. It begins by discussing issues that have surfaced in the definition of LLS in terms of determining whether it is conscious or unconscious in nature. Debates pertaining to LLS definition have also been muddled with issues concerning the nature of learning strategy either as an action, or a mental activity or both. Some changes in the pattern of definitions that scholars created have been identified. These include the change in focus from product to process and the change in terms of the definitions' comprehensiveness, among others. The influence of cognitive and social cognitive theories in defining LLS has also been observed after more than ten years of study in this field. As a result, this paper affirms that the main frame for the definition of LLS involves two components which are elements and purpose.
\end{abstract}

Keywords: language learning strategy, second language learning, foreign language learning, cognitive theory, social cognitive theory

\section{Introduction}

Research on Language Learning Strategies (LLS) was initiated by "Good Language Learner" studies (e.g., Naiman, Frohlich, Stern, \& Todesco, 1978; Rubin, 1975; Stern, 1975). These studies showed that one of the characteristics of excellent students is their use of learning strategies. Their assumption was that once successful learning strategies were identified, they could be taught to less successful learners to make them more effective learners. Following that, various studies have examined the relationship between LLS usage and language proficiency.Some researchers attempted to explore whether language students who perform well use LLS frequently and in large numbers (e.g., Green \& Oxford, 1995). Some studies 
investigated whether the total number and frequency of LLS usage contribute towards the progress of language skills (e.g., Park, 1997), while others focussed on the relationship of cause and effect which shows that the use of strategy and level of language proficiency complement each other (e.g., Bremner, 1999). These studies indicate the importance of LLS in language learning and the effects in improving the level of language proficiency, skills, and achievement of students. In more recent years, this growing awareness has resulted in what Skehan (1989) calls an "explosion of activity" in the field of LLS research (p. 285).

In the early stages, studies on Second Language Learning Strategy were more inclined towards the use of "research first, theory later" approach (Skehan, 1989). At the time, LLS research was not based on a solid theory. After the emergence of the Cognitive Learning Theory, most LLS researchers began to use the theory as a theoretical frame for their researches (Griffiths, 2003; Macaro, 2001; O'Malley, Chamot, \& Walker, 1987; Oxford, 1990; Purpura, 1999). This is because in their opinion, a learning strategy does not differ much from a cognitive process. Both focus on issues as to how students save, recall and obtain information when learning a new knowledge or skill (Anderson, 1983, 1985).

Apart from that, the situation of a newly learned language having the possibility of being in the context of learning a second or foreign language has often led to the construction of "Language Learning Strategy" terminologies which lack unanimity and uniformity (Gass \& Selinker, 2001; Oxford \& Cohen, 1992). Some researchers use the term "learner strategies" (Wenden \& Rubin, 1987) or the expression "learning strategies" (O'Malley \& Chamot, 1990), whilst the others would call it "language learning strategies" (Oxford, 1990). Additionally, there are several terms that are often used in LLS literature such as techniques (Stern, 1983), tactics (Seliger, 1983) or something similar. These different expressions imply the absence of consensus in the literature concerning either the definition or the identification of learning strategies.

The absence of theory in early LLS research and the existence of different learning contexts have led to a complicated and tedious process of defining LLS. O'Malley, Chamot, Stewner-Manzanares, Russo, and Kupper (1985) mentioned that there is no consensus on what constitutes a learning strategy in second language learning or how these differ from other types of learner activities. There is considerable confusion on definitions of specific strategies and the hierarchic relationship among strategies. Gu (1996) also pointed out that there has yet to exist a general developmental pattern in the conception of learning strategies. Hence, the definitions that were presented seemed to be somewhat fuzzy (Ellis, 1994). This situation has resulted in conflicting views among researchers (Cohen, 1999).

\section{Definition of LLS}

The word strategy originated from the ancient Greek word "strategia", which means the art of war or generalship dealing with the optimal management of troops, ships, and aircraft in wars. Later, the competitive aspect of strategy use spreads into nonmilitary setting and non adversarial situations, where it has come to mean a plan, 
step or conscious action toward achievement of an objective (Oxford, 1990). Not until recently did the concept of strategy enter into education, where it has taken on a new meaning and has been transformed into learning strategy.

As one of the earliest researchers in this field, Rubin (1975) provided a very broad definition of LLS as the techniques or devices which a learner may use to acquire knowledge. Rigney (1978) defined LLS as the often conscious steps and behaviours used by learners to enhance acquisition. Bialystok (1978) stated that strategies are optional means for exploiting available information to improve competence in a second language. Faerch and Kasper (1983) stress that a LLS is an attempt to develop linguistic and sociolinguistic competence in the target language.

Wenden and Rubin (1987) defined LLS as strategies which contribute to the development of the language system where the learner constructs and affects learning directly. O'Malley and Chamot (1990) offered another definition of LLS as special thoughts or behaviours that individuals use to help them comprehend, learn, or retain new information.

Ehrman and Oxford (1990), on the other hand, viewed LLS as the often conscious steps or behaviours that learners adopt to assist their learning. Nyikos (1991) looked at LLS as strategic techniques used by language students to understand and process new information more deeply, to help them recall old information, and apply knowledge and skills to simplify problem solving. According to Ellis (1994), LLS refer to mental or behavioural activities related to some specific stages in the overall process or language acquisition or language use. Reid (1995), when elaborating the relationship and differences between language learning strategy and style, defined LLS as natural, habitual, and preferred ways of absorbing, processing, and retaining new information and skills. Mohamed Amin Embi (1996) defined LLS as plans and/or actions that learners take to enhance their process of language learning. Leaver, Ehrman, and Shekhtman (2005) defined it as specific actions and/or techniques used for learning.

In general, scholars have come up with various LLS definition since the early stages of LLS. They tried their best to explain the meaning, characteristics and activities of LLS. Therefore, the purpose of this paper is to identify developmental issues and patterns that emerge from the the process of defining LLS.

\section{Definition issues}

Among issues that often arise while defining LLS are whether it is "conscious" or "unconscious", and "intentional" or "unintentional" in nature. Some of the researchers were of the opinion that "unconscious" or "unintentional" is a form of strategy. Tudor (1996) described LLS as an action taken by students whether consciously or unconsciously for the purpose of expanding and improving their speaking, listening, reading and writing skills in a foreign or second language. Purpura (1997) defined LLS as conscious or unconscious mental or behavioural activities that relate directly or indirectly to specific stages in the process of second language acquisition. Nisbet (1986) stated that LLS is always purposeful and goaloriented, but perhaps not always carried out at a conscious or deliberate level. They can be lengthy or so rapid in execution that it is impossible for the learner to 
recapture, recall or even be aware that one has used a strategy. Leaver et al. (2005) was of the opinion that part of the LLS is used consciously and the other part, automatically.

Among those who characterised LLS as a process that occur "consciously" or "intentionally" was Stern (1992) who believed that learning strategy concept depends on an assumption that students consciously perform activities to achieve certain goals, and learning strategies can be considered as instructions and learning techniques that are intentional. Richard and Platt (1992) stated that LLS are intentional behaviours and thoughts used by learners during learning so as to better help them understand, learn or remember new information. Maclntyre (1994) defined LLS as the actions chosen by language students that are intended to facilitate language acquisition and communication. Grainger (1997) looked at LLS as a specific technique or action used consciously by a student to help in various aspects or aspect of language learning. According to Reid (1998), LLS is an external skill that is frequently used by students consciously to enhance learning.

The words "conscious", "intentional", and "student preference" that are frequently mentioned in the definitions show that LLS can only be categorised as strategies when they are thoughts and intentional or conscious actions to enhance language learning process. Cohen (1999) defined LLS as processes which are consciously selected by learners and which may result in action taken to enhance the learning or use of a second or foreign language, through the storage, retention, recall, and application of information about the language. It is believed that the element of consciousness is important to LLS concept because it distinguishes strategies from those processes that are not strategic. It has been explained that if the behaviour is so unconscious that the learners are not able to identify any strategy associated with it, then behaviour can be referred to as a process and not a strategy. It has also been emphasised that the learners who select learning strategies must be at least partially aware of them even if they are not attending to them fully. Ellis (1994) pointed out that if strategies become so automatic that the learners are no longer conscious of employing them, they are no longer accessible for description through verbal report by the learners and thus lose their significance as strategies. Without the consciousness characteristic, students will certainly not be able to identify and describe the type of actions resulting from it.

As with other complex procedures, LLS also occur in a conscious, intentional, and controlled state from the beginning of learning process before they change to automatic state. LLS then cannot be considered a strategic action anymore. Oxford and Cohen (1992) believed that when a strategy has become habitual or automatic, the strategy has transformed into a process by itself. Griffiths (2003) defined LLS as specific actions consciously employed by the learner for the purpose of learning language. This definition includes Oxford's (1990) concept of LLS as specific action taken in order to learn language, and Cohen's (1999) dimension of conscious selection. Indirectly, this definition is seen to be able to differentiate between language learning strategy and language learning style.

Another problematic issue is the absence of consensus as to whether strategies need to be behavioural (observable), or mental (unobservable) processes, or both in order for them to be considered strategies. Stern (1983) and Oxford 
(1990) appear to see LLS as essentially behavioural. Oxford (1990), for instance, defined LLS as behaviours or actions which learners use to make language learning more successful, self-directed and enjoyable. Meanwhile, Weinstein and Mayer (1986), O'Malley and Chamot (1990), and Ellis (1994) see them as both behavioural and mental.

\section{Development of Definition}

From the definitions given, the change of focus from "product" to "process" is clearly visible. In the beginning of LLS research era, definitions were more focussed on improving language competence (Bialystok, 1978; Rubin, 1975) as a product of LLS usage. Then it changed to facilitating language learning (Brown, 1994; Chamot, 1987), and continued on to making language learning more enjoyable (Oxford, 1990). Thus, the purpose of LLS has changed from producing good learners who speak a target language fluently, to producing intelligent learners who know very well about how to learn a second or foreign language more successfully. In other words, it has expanded to the extent of making LLS process and characteristics a priority and important elements in forming the definition.

All at once, LLS objective has slowly changed from producing language students who are successful and able to speak in second language fluently to producing language students who are wise and intelligent and know sufficiently how to learn a second language more successfully (Tamada, 1997).

From a different angle, LLS have progressed from being defined in a simple and brief manner to being delineated in a more comprehensive way As mentioned before, for earlier works, Rubin (1975) used the term "strategies" in a narrow sense. Later, Rubin (1987) clarified the definition and stated that LLS are strategies which contribute to the development of the language system which the learner constructs. Weinstein and Mayer (1986) defined LLS as behaviours and thoughts that a learner engages in during learning which are intended to influence the learner's encoding process. Mayer (1988) then defined it as behaviours of a learner that are intended to influence how the learner processes information.

Brown (1994) in short, defined LLS as a process that contributes directly to learning. Then Chamot (1987) expanded the LLS definition given by Brown (1994) to become techniques, approaches or deliberate actions that students take in order to facilitate the learning and recall of both linguistic and content area information. Park (1997) maintained that LLS facilitates second language acquirement by stimulating more and better inputs by processing inputs to be taken in, and through production of outputs. Inputs are thought to be obtainable through learning, but the usage of strategy will help more, faster and better input acquirement. Nunan's (1999) comprehensive definition looks at LLS as mental and communicative procedures learners use in order to learn and use language.

Oxford (1990), on the other hand, expanded Rigney's original definition and defined LLS as specific actions taken by the learner to make learning easier, faster, more enjoyable, more self-directed, more effective, and more transferable to new situations. The author provides one of the most comprehensive definitions which 
also emphasise the importance of affective and social aspects of language learning strategies.

\section{Theory underpinning language learning strategy research}

As mentioned earlier, LLS research in the early stages was not based on any theory. The research literature in the 1970 s and 80 s can be understood as representing a growing level of sophistication in conceptualising LLS together with methodological advances leading to further empirical studies to test emerging hypotheses. Increasingly, in these early works, it became evident that a clear and precise theoretical framework was needed which would take strategy research beyond the utilitarian and pragmatic (Grenfell \& Macaro, 2011). Then, after the 10 years, cognitive psychology theories began to influence LLS research and also shaped the definition of LLS (O'Malley \& Chamot, 1990).

Cognitive and social cognitive learning models are two major theoretical frameworks which have provided rationales for the use and development of LLS. Cognitive psychologists view learning as an active, dynamic process, in which the learners select from incoming information, encode it into their long term memory and retrieve it when needed (Anderson, 1983, 1985; McLaughlin, 1987). Social cognitive psychologists have also contributed to the theories of LLS. They emphasise the impact of social and cultural factors on human learning. The theory basically assumes that language learning acquisition take place through the interaction of learner and more advanced interlocutor (Bandura, 1986; Vygotsky, 1978). These cognitive learning theories and social cognitive models have been applied to the field of LLS by researchers such as O'Malley and Chamot (1990), Oxford (1990), Macaro (2001), and Griffiths (2003). All these underpinning theories have provided the framework to formulate the definition and classify the strategies.

Even though researchers constructed LLS definitions using a variety of expressions and different points of view in several issues, almost all described how much LLS is centered around cognitive and social cognitive theories involving information processing, and interpersonal and intrapersonal interactions. Cognitive theory has left a great impact on the formation of LLS so much so that the characteristics of information processing are clearly visible on some of the definitions given (Kamarul Shukri \& Mohamed Amin Embi, 2010). For instance, Weinstein and Mayer (1986) defined LLS as "actions and thinking used by students while learning with a hope to facilitate coding process" (p. 315). Mayer (1988) then specified LLS definition as "actions of students with a purpose of facilitating information processing" (p. 11). Anchored on social cognitive learning theory, the LLS field does not look at language learning as solely information processing related to grammar, vocabulary and phonetic system. Instead, it requires individual participations in the socialising process through interpersonal and intrapersonal interactions (Kamarul Shukri \& Mohamed Amin, 2010). As Tarone (1981) notes, learning strategies are attempts to develop linguistic and sociolinguistic competence in the target language. Hence, the LLS definitions take the social and cultural impacts on human learning seriously. Differences in opinions which did not drag the 
definitions outside the theoretical framework had proven the stability and strength of the theory, and also the maturity and strengthening of LLS definitions thereafter.

\section{Framework of Definition}

While analysing the definitions of LLS, scholars were often found to consider two components in their definition formation process. The components are:

1. Element - refers to features and characteristics of strategy.

2. Purpose - refers to reason why the said strategy is used.

The components can be considered as the main frame in defining LLS. This is clearly visible in several LLS main definition options as shown in Table 1. Among the elements frequently shown by those definitions are actions, thoughts, operations, and planning. Additionally, the purposes of strategy usage frequently mentioned are to facilitate learning and information processing, and improving language skills and achievement.

Table 1

Main LLS definitions

\begin{tabular}{|c|c|c|}
\hline Researcher & Element & Purpose \\
\hline Rubin (1975) & Technique or planning. & To acquire knowledge. \\
\hline Bialystok (1978) & Conscious method/effort. & $\begin{array}{l}\text { To exploit any information that can be } \\
\text { acquired to improve second language skills. }\end{array}$ \\
\hline Chamot (1987) & $\begin{array}{l}\text { Technique, approach, and } \\
\text { intentional action. }\end{array}$ & $\begin{array}{l}\text { To facilitate learning and recall process of } \\
\text { both the linguistic aspect and content of any } \\
\text { information. }\end{array}$ \\
\hline Rubin (1987) & $\begin{array}{l}\text { Operation network, steps, } \\
\text { planning, routine carried } \\
\text { out by students. }\end{array}$ & $\begin{array}{l}\text { To facilitate acquirement, saving, recall and } \\
\text { usage of information. }\end{array}$ \\
\hline $\begin{array}{l}\text { O'Malley and } \\
\text { Chamot (1990) }\end{array}$ & $\begin{array}{l}\text { Specific thought or } \\
\text { behavior. }\end{array}$ & $\begin{array}{l}\text { To facilitate understanding, learning and } \\
\text { retention of new knowledge. }\end{array}$ \\
\hline Oxford (1990) & Specific action. & $\begin{array}{l}\text { To make learning easier, faster, and more fun, } \\
\text { more in the form of self access, more } \\
\text { effective, and more adaptable to new } \\
\text { situation. }\end{array}$ \\
\hline Maclntyre (1994) & Actions. & $\begin{array}{l}\text { To facilitate language acquisition and } \\
\text { communication. }\end{array}$ \\
\hline Nunan (1999) & $\begin{array}{l}\text { Mental and communicative } \\
\text { procedure. }\end{array}$ & To learn and use language. \\
\hline
\end{tabular}




\begin{tabular}{|c|c|c|}
\hline Cohen (1999) & $\begin{array}{l}\text { Learning process chosen or } \\
\text { carried out consciously. }\end{array}$ & $\begin{array}{l}\text { To improve learning or usage of target } \\
\text { language through storage, retention, recall } \\
\text { and application of information. }\end{array}$ \\
\hline $\begin{array}{l}\text { Mohamed Amin } \\
\text { Embi (2000) }\end{array}$ & Planning and/or action. & To enhance learning process. \\
\hline
\end{tabular}

\section{Conclusion}

"Research first, theory later" orientation in the early stage of LLS study has led to unclear definitions, inconsistent terms, and caused conflicting views among LLS scholars and researchers. However, Table 1 shows that the LLS defining process at last had reached a maturity stage. When this process was going on, there were several definition issues and developments. Some scholars placed "conscious" and "unconsious" as the characteristics of LLS, whereas others consider "conscious" as an attribute of LLS. A person is not said to use a learning strategy when he is not aware of what he is doing. The issue of whether or not LLS is an action, a mental activity or both also grabbed the attention of researchers. Most scholars are more inclined to desribe LLS as something that involves mental activities and actions. LLS definition has also expanded from being focussed on solely "results" to "process" of LLS usage. Definitions also changed from being simple in nature to more comprehensive. The final definition was also based on cognitive and social cognitive theories by highlighting their elements in the definition formation process. Besides that, "element" and "purpose" have been identified as two components which often become the main frame in defining LLS.

In short, LLS can be defined as specific steps or actions taken by students to facilitate acquisition, storage or retrieval of information until learning becomes easier, faster, more enjoyable, more self directed, more effective, and easier to be moved to a new situation. It involves mental and communicative procedures to learn and use language in the improvement and mastery of target language main frame.

\section{References}

Anderson, J. R. (1983). The architecture of cognition. Cambridge, MA: Harvard University Press.

Anderson, J. R. (1985). Cognitive psychology and its implication. New York, Freeman.

Bandura, A. (1986). Social functions of thought and action: A social cognitive theory. Englewood Cliffs, NJ: Prentice Hall.

Bialystok, E. (1978). A theoretical model of second language learning. Language Learning, 28, 69-83.

Bremner, S. (1999). Language learning strategies and language proficiency: Investigating the relationship in Hong Kong. The Canadian Modern Language Review, 55(4), 490-514. 
Brown, H. D. (1994). Principles of language learning and teaching. Englewood Cliffs, NJ: Prentice Hall.

Chamot, A. U. (1987). The learning strategies of ESL students. In A. Wenden \& J. Rubin (Eds.), Learner strategies in language learning (pp. 71-83). Englewood Cliffs, NJ: Prentice Hall.

Cohen, A. D. (1999). Strategies in learning and using a second language. London, UK: Longman.

Ehrman, M. E., \& Oxford, R. L. (1990). Adult language learning styles and strategies in intensive training setting. Modern Language Journal, 74(3), 311-327.

Ellis, R. (1994). The study of second language acquisition. Oxford, UK: Oxford University Press.

Faerch, C., \& Kasper, G. (1983). Procedural knowledge as a component of foreign language learners' communicative competence. In H. Boete \& W. Herrlitz (Eds.), Kommunicationim (Sprach) Unterricht (pp. 169-199). Utrecht, Netherlands: Rijksuniversiteik.

Gass, S. M., \& Selinker, L. (2001). Second language acquisition: An introductory course. Mahwah, NJ: Lawrence Erlbaum Associates.

Grainger, P. R. (1997). Language learning strategies for learners of Japanese: Investigating ethnicity. Foreign Language Annals, 30(3), 378-385.

Green, J. M., \& Oxford, R. L. (1995). A closer look at learning strategies, L2 proficiency, and gender. TESOL Quarterly,29(2), 261-297.

Grenfell, M., \& Macaro, E. (2011). Claims and critiques. In A. D. Cohen \& E. Macaro (Eds.), Language learner strategies (pp. 9-28). Oxford, UK: Oxford University Press.

Griffiths, C. (2003). Language learning strategy use and proficiency: The relationship between patterns of reported language learning strategy (LLS) use by speakers of other languages (SOL) and proficiency with implications for the teaching/learning situation. Unpublished doctoral thesis, University of Auckland, New Zealand.

Gu, P. Y. (1996). Robin Hood in SLA: What has the learning strategy research taught us? Asian Journal of English Language Teaching,6, 1-29.

Kamarul Shukri Mat Teh \& Mohamed Amin Embi. (2010). Strategi pembelajaran bahasa. Kuala Lumpur, Malaysia: Penerbit Universiti Malaya.

Leaver, B. L., Ehrman, M., \& Shekhtman, B. (2005). Achieving success in second language acquisition. Cambridge, UK: Cambridge University Press.

Macaro, E. (2001). Learning strategies in foreign and second language classrooms. London, UK: Continuum.

Macintyre, P. D. (1994). Toward a social psychological model of strategy use. Foreign Language Annals, 27(2), 185-195.

Mayer R. (1988). Learning strategies: An overview. In C. Weinstein, E. Goetz, \& P. Alexander (Eds.), Language and study strategies: issues in assessment, instruction and evaluation (pp. 11-22). New York, NY: Academic Press.

McLaughlin, B. (1987). Theories of second language learning. London, UK: Edward Arnold. 
Mohamed Amin Embi. (1996). Language learning strategies employed by secondary school students learning English as a foreign language in Malaysia. Unpublished doctoral thesis, University of Leeds, United Kingdom.

Mohamed Amin Embi. (2000). Language learning strategies: A Malaysian context. Bangi, Malaysia: Penerbit Universiti Kebangsaan Malaysia.

Naiman, N., Frohlich, M., Stern, H., \& Todesco, A. (1978). The good language learner. Research in Education Series No 7. Toronto, Canada: The Ontario Institute for Studies in Education.

Nunan, D. (1999). Second language teaching and learning. Massachusetts, MA: Heinle \& Heinle Publishers.

Nyikos, M. (1991). Prioritizing student learning: a guide for teachers. In L. Strasheim (Ed.), Focus on the foreign language learner: priorities and strategies (pp. 2539). Lincolnwood, IL: National Textbook.

O'Malley, J. M., \& Chamot, A.U. (1990). Learning strategies in second language acquisition. Cambridge, UK: Cambridge University Press.

O'Malley, J. M., Chamot, A. U., \& Walker, C. (1987). Some applications of cognitive theory to second language acquisition. Studies in Second Language Acquisition, 9, 287-306.

O'Malley, J. M., Chamot, A. U., Stewner-Manzanares, G., Russo, R. P., \& Kupper, L. (1985). Learning strategies applications with students of English as a second language. TESOL Quarterly, 19, 557-584.

Oxford, R. L. (1990). Language learning strategies: What every teacher should know. New York: Newbury House.

Oxford, R. L., \& Cohen, A. D. (1992). Language learning strategies: Crucial issues of concept and classification. Applied Language Learning, 3(1-2),1-35.

Park, G. P. (1997). Language learning strategies and English proficiency in Korean university students. Foreign Language Annals, 30(2), 211-221.

Purpura, J. M. (1997). An analysis of the relationships between test takers' cognitive and metacognitive strategy use and second language test performance. Language Learning, 47(2), 289-325.

Purpura, J. M. (1999). Learner strategy use and performance on language tests: A structural equation modeling approach. Cambridge, UK: Cambridge University Press.

Reid, J. M. (1995). Learning styles in the ESL/EFL classroom. Boston, MA: Heinle \& Heinle.

Reid, J. M. (1998). Understanding learning styles in the second language classroom. Englewood Cliffs, NJ: Regents Prentice Hall.

Richard, J., \& Platt, J. (1992). Longman dictionary of language teaching and applied linguistics. Essex, UK: Longman.

Rigney, J. W. (1978). Learning strategies: A theoretical perspective. In H. F. O'Neil, Jr. (Ed.), Learning strategies (pp. 164-205). New York, NY: Academic Press.

Rubin, J. (1975). What the good language learner can teach us. TESOL Quarterly, 9(1), 41-51.

Rubin, J. (1987). Learners strategies: theoretical assumptions, research history and typology. In A. Wenden \& J. Rubin (Eds.). Learner strategies in language learning (pp. 15-29). Englewood Cliffs, NJ: Prentice Hall. 
Seliger, H. W. (1983). The language learner as linguist: of metaphors and realities. Applied Linguistics, 4(3), 179-191.

Skehan, P. (1989). Individual differences in second language acquisition. New York: Edward Arnold.

Stern, H. H. (1975). What can we learn from the good language learners? Canadian Modern Language Review, 31(3), 304-318.

Stern, H. H. (1983). Fundamental concepts of language teaching. Oxford, UK: Oxford University Press.

Stern, H. H. (1992). Issues and options in language teaching. Oxford, UK: Oxford University Press.

Tamada, Y. (1997). The review of studies related to language learning strategies. ERIC Document Reproduction Services. Retrieved from ERIC database (ED404857).

Tarone, E. (1981). Some thoughts on notion of communication strategy. TESOL Quarterly, 15, 285-295.

Tudor, I. (1996). Learner-centeredness as language education. Cambridge, UK: Cambridge University Press.

Vygotsky, L. S. (1978).Mind in society: The development of higher psychological processes. Cambridge, MA: Harvard University Press.

Weinstein, C. E., \& Mayer, R. E. (1986). The teaching of learning strategies. In M. C. Wittrock (Ed.), Handbook of research on teaching (pp. 315-327). New York: MacMillan.

Wenden, A. L., \& Rubin, J. (Eds.). (1987). Learner strategies in language learning. New Jersey: Prentice Hall. 